\title{
Zinc Finger Protein RLF
}

National Cancer Institute

\section{Source}

National Cancer Institute. Zinc Finger Protein RLF. NCI Thesaurus. Code C104754.

Zinc finger protein RLF (1914 aa, $218 \mathrm{kDa}$ ) is encoded by the human RLF gene. This protein may play a role in DNA binding and transcriptional regulation. 